\title{
A atração pelo desconhecido e a visão da América na obra de Marie van Langendonck
}

\author{
The attraction of the unknown and the vision of America in the work of Marie van Langendonck
}

\author{
Pamela Pinto Chiareli Fachinelli \\ Instituto Federal de Educação, Ciência e Tecnologia do Triângulo Mineiro - Minas Gerais - Brasil \\ Joana Luiza Muylaert de Araújo \\ Universidade Federal de Uberlândia - Minas Gerais - Brasil \\ Fani Miranda Tabak \\ Universidade Federal do Triângulo Mineiro - Minas Gerais - Brasil
}

\begin{abstract}
Resumo: O livro Uma Colônia no Brasil que é pouco conhecido no meio acadêmico. Escrito por uma belga, Madame van Langendonck, relata as experiências da autora em terras brasileiras no período em que residiu em uma colônia ao sul do país, entre os anos de 1857 e 1859. Marie van Langendonck, aos sessenta anos, embarcou em um navio de emigrantes seduzida pelo desejo de vivenciar a floresta virgem do Brasil. Acredita-se que a viajante tenha absorvido a visão edênica de um mundo virgem revivida no Romantismo. Assim, busca-se discutir a construção do imaginário europeu acerca da natureza americana e seu impacto na obra de Marie.

Palavras-chave: Uma colônia no Brasil; Madame van Langendonck; Literatura de viagem
\end{abstract}

\begin{abstract}
The book Uma Colonia no Brasil that is almost unknown in the academy. It was written by a belgium, Madame van Langendonck and has the purpose of describing her experiences in the Brazilian lands in the period she lived in a colony located in the south of the country, in the years 1857 to 1859 . At sixty, Marie van Langendonck boards in an emigrant ship seduced by the desire of living in a virgin forest in Brazil. As soon as we believe the traveler had assimilated the edenic vision of a virgin world relived in the Romantic period, we intend to discuss the construction of the European American imaginary about nature and its impact on the work of Marie van Langendonck.
\end{abstract}

Keywords: A Colony in Brazil; Mme. van Langendonck; Travel literature

\section{Introdução}

Marie Barbe Antoinette Rutgeerts van Langendonck nasceu em sete de outubro de 1798, em Antuérpia (Bélgica). No ano de 1827 casou-se em sua cidade natal com Jean Remi Félicien Philippe van Langendonck, oficial do Régiment de Guide e diretor do Hospital Militar de Charleroi. Uma ilustre dama, educada segundo os moldes europeus, poetisa e escritora, com várias obras publicadas, entre elas, Aubepines (1841) e Heures poétiques (1846). Em 30 de abril de 1857, então viúva, Mme. van Langendonck deixou a vida confortável que levava na Bélgica e embarcou no brigue Amanda, com destino ao porto de Rio Grande, no Brasil. No dia nove de julho chegou ao porto e ficou aproximadamente dez dias em Porto Alegre, seguiu depois para a Colônia
Harmonia, propriedade do vice-cônsul da França, Conde de Montravel - tratava-se de grande propriedade que a sociedade de Montravel alugava para ali instalar, provisoriamente, seus escritórios e para oferecer pouso aos colonos chegados da Europa. Por fim, Marie estabeleceuse em Santa Maria de Soledade, colônia onde seus filhos a esperavam. O relato de Mme. van Langendonck incluiu os percalços da viagem no navio de emigrantes que a trouxe, descrevendo a sua experiência como colona, suas tentativas de estabelecer-se em uma região agrícola, com desmatamento, plantações de milho e feijão, e o enfrentamento de todos os perigos de uma região isolada e ainda selvagem. Decorridos dois anos no Rio Grande do Sul, voltou à Bélgica, mas em 1863, movida pela saudade dos filhos e do país, retornou ao Brasil. Continuou no país, precisamente no Rio Grande do Sul, até falecer 
em 1875, no município de Arroio Grande. Alguns fatores foram fundamentais para a vinda de Marie para o Brasil, entre os quais eram a crise econômica europeia e a morte do marido. A possibilidade de erguer-se financeiramente em uma colônia de terras férteis no Brasil foi associada a uma aspiração antiga, uma vez que, para ela o que a atraia ao Brasil, um país desconhecido, era, além da necessidade financeira, o desejo intenso de ver uma floresta virgem, de estar em contato com a natureza intocada, tão viva em relatos de viajantes no decorrer dos séculos, o que já não era possível encontrar no Velho Mundo.

Em Uma colônia no Brasil, a narradora revela-se, inicialmente, como uma mulher desprovida de julgamentos e preconceitos eurocêntricos acerca da população que ali se encontrava e de sua organização política, porém, é no desenrolar de suas descrições que nota-se quão arraigada estava a visão europeia de soberania sobre os povos conquistados. Centrada na visão oitocentista do Novo Mundo, a autora relatou sua passagem pelo Brasil como moradora de uma cabana em meio à mata virgem, tendo recusado uma colônia mais próxima da civilização. À escolha incivilizada de Marie pode-se agregar aos fenômenos que marcaram, desde a colonização, a conquista do espaço americano e a permanência de contingente humano no mesmo. No Brasil oitocentista houve, desde logo, grande interesse em atrair mercenários para reforçar as tropas militares imperiais no processo de independência, bem como camponeses para trabalhar como colonos. Naquela ocasião, surgiram as chamadas campanhas migratórias que incentivavam os europeus a emigrarem para o Brasil em busca de melhores condições de vida. Os agentes dessas campanhas passavam às camadas mais pobres da Europa, a imagem de que as terras brasileiras eram "verdadeira Terra de Promissão, onde haveria ouro como areia, as batatas seriam do tamanho de uma cabeça, o café cresceria em todas as árvores e o verde seria eterno" (SUSSEKIND, 1990, p. 22).

Atraídos pelos engodos da campanha colonialista, muitos europeus emigraram para o Brasil, entre os quais, a família de Marie van Langendonck. Seus filhos saíram de Antuérpia engajados no projeto de Conde de Montravel e emigraram para participar da criação de uma colônia no Rio Grande do Sul, com o intuito de enriquecerem. Além da conveniência financeira, Marie enxergou a ocasião como uma oportunidade de conhecer a mata virgem que tanto desejou, de modo a afirmar não ser importante o que ela faria no Brasil, mas sim o que veria. Completamente ligada à sua percepção e ao desejo de conhecer as florestas virgens brasileiras, está a 'atração pelo desconhecido' que atuou em si como motivação interior, noção romântica já abordada por Benedito Nunes no trato do Romantismo (2011). Dessa maneira, o fato de Marie deixar-se envolver e seduzir pelo estranho - entendido aqui como aquilo que é desconhecido -, pela natureza intocável e exótica, de modo a não se preocupar, antes de tudo, com os percalços financeiros e o processo de adaptação à vida rudimentar na colônia, leva-se à constatação de que seu discurso incorporava parte do sentimento que dominou a cultura e a sociedade europeia nos fins do século XVIII até meados do século XIX, dentro da chamada visão romântica:

[...] a busca do sublime ou exótico, dos recantos solitários que tranquilizam, das paisagens remotas que acendem o desejo da terra paradisíaca, ou de lugares em ruínas, abandonados pelo homem, que despertam a nostalgia da terra perdida - por trás desses aspectos do culto da Natureza, enquadrados num confronto dramático com o mundo, está silhuetada a tácita insatisfação com o todo da cultura, misto de afastamento desencantado e de reprovação à sociedade, depois do assomo libertário do idealismo político de 1789 (NUNES, 2011, p. 69).

O sentimento que dominou a sociedade europeia, reiterado por Nunes (2011), estabeleceu a distinção entre as categorias psicológica e histórica implícitas no conceito de Romantismo. Enquanto a categoria histórica está ligada ao movimento literário e artístico datado, o romantismo psicológico é uma forma de sensibilidade que traz um caráter de inquietude, de insatisfação permanente, um conflito interior que traduz uma forma e concepção de mundo decorrentes das revoluções Industrial e Francesa e, que se concretizou no plano artístico e literário. Ao substituir a visão macrocósmica que os clássicos tinham da vida e da arte, por uma visão microcósmica, centrada no 'eu' de cada sujeito, os românticos deram vazão ao individualismo, instruindo a 'noção de percepção', termo ligado à estética, de forma que cada indivíduo fosse agente de criação. Essa transformação nos princípios que regem a arte dialoga com a crise da representação, marcada pela passagem do Antigo Regime para a modernidade. Nessa nova esfera estética, a representação torna-se uma forma inventiva de criação, abdicando do conceito mimético de cópia e imitação, ainda que não esteja totalmente destituída de valores universais.

Dentro de uma nova concepção gestacional para a arte encontra-se um elemento fundamental: a natureza. É um tema constante desde tempos remotos; a natureza passa a receber um novo valor estético. Para os clássicos, a natureza é regida por leis universais que lhe conferem harmonia e, à medida que "a obra de arte é a imitação da natureza e, imitando-a, imita seu concerto harmônico, sua racionalidade profunda, as leis do universo" (ROSENFELD; GUINSBURG, 2011, p.263), o valor estético concentra-se na capacidade mimética da obra, uma vez que o escritor clássico deveria dominar os ímpetos da interioridade e no plano expressivo trabalhar 
como uma espécie de artesão que se ajusta às regras estabelecidas. Fugir ao ajuste, à medida, os românticos apreendem a natureza segundo um novo conceito de expressão, sendo o equilíbrio entre o eu e o mundo, entre a racionalidade e a subjetividade, consequentemente, o caráter de novidade é atribuído à obra na medida em que ela consegue expor uma forma particular de apreender o mesmo objeto. Assim, acreditaram que os valores universais de beleza continuariam a existir e a percepção do escritor seria o que de fato tornaria a obra de arte individual e, em certa medida, nova. Constituiu-se como um pensamento orgânico e, portanto, reinterpretando o conceito de mimese, o poeta romântico é movido por um dom inato, pela intuição ou predestinação e funciona como o mediador entre o Eu e a natureza. Diante disso, a natureza representa uma espécie de espelho onde o homem busca reencontrar-se consigo mesmo, em uma tentativa de harmonia e conciliação com o mundo externo, inadequado por excelência. Encontrar-se com a natureza, portanto, implica em alargar a sensibilidade, vendo nesse elemento uma espécie de antítese da civilização que os oprime. Em constante desilusão com a sociedade, o romântico transforma a Natureza em teofania, acredita que ela é a manifestação do poder divino. Logo, quanto mais próximos das formas naturais, mais próximos estariam de Deus. Mme. van Langendonck corrobora essa sacralização da natureza em meio ao reconhecimento de que o Brasil é um país jovem, promissor, como se vê no exemplo abaixo:

A casa estava em ruínas; apenas o quarto que eu ocupara continuava de pé; o negro que guardava a propriedade morava ali. [...]. Sentei por entre os escombros que faziam a solidão parecer mais severa e menos jovem a terra. As ruínas são coisas raras no Brasil, aquelas foram as únicas que vi. Olhando-as, comparei involuntariamente essas obras do homem, que duram tão pouco, com essas vastas florestas que eu acabava de atravessar, que o tempo torna mais belas e majestosas, enquanto destrói tudo aquilo que o homem se esforça para tornar durável. (LANGENDONCK, 2002, p. 103)

As ruínas a que a narradora se refere são o que sobrou da sede da sociedade de Montravel, a mesma que a recebera, dois anos antes, quando chegara ao Brasil. É por meio delas que Marie estabeleceu uma comparação entre as obras do homem, que se acabam, e as obras divinas, que podiam durar para sempre se não fosse a intervenção humana. A partir do desenvolvimento do pensamento romântico em relação à natureza, países detentores de uma natureza exuberante, como aqueles da América, tornaram-se objeto de enlevo, admiração e fonte de inspiração de novos conteúdos ou de formas distintas de escrita, estabelecendo uma espécie de retorno aos motivos edênicos desde os primórdios da presença europeia. A imagem dos trópicos, no entanto, constitui um elemento paradoxal desde os primeiros cronistas e viajantes que aportaram na América.

\section{Visão da América}

Uma das primeiras notícias sobre a América foi transmitida por meio da carta de Cristóvão Colombo a Luis de Santángel, em 1493. Sua proposição registrava suas recentes descobertas acerca das ilhas em que havia aportado. $\mathrm{O}$ deslumbramento era o tom que mediava as descrições de Colombo sobre o lugar e o contato com o habitante estava influído pela corrente da mitologia europeia que pensava que os povos primitivos estavam mais próximos das condições do Jardim do Éden do que os povos imersos nos conflitos da 'civilização'. Uma vez que, até aquele momento, não havia relatos acerca dessas terras, os letrados europeus se referiram ao continente americano como o Novo Mundo. Segundo Holanda (1996, p. 210):

[...] novo, não só porque, ignorado até então, das gentes da Europa e ausente da geografia de Ptolomeu, fora 'novamente' encontrado, mas porque parecia o mundo renovar-se ali, e regenerar-se, vestido de verde imutável, banhado numa perene primavera, alheio à variedade e aos rigores das estações, como se tivesse verdadeiramente restituído à glória dos dias da Criação.

A passagem, presente em Visão do Paraíso (1996), conforma o arrebatamento de Colombo acerca das terras americanas e, apesar de não conter dados sobre os habitantes desse lugar, refere-se à 'glória dos dias da Criação'. Dessa maneira, a natureza exuberante, rica em recursos naturais, em constante clima primaveril, coexistindo com seus habitantes de atitude afável e ingênua - assemelhando-se à imagem de Adão e Eva vivendo no Éden, antes do pecado original - leva o colonizador a atribuir ao Novo Mundo, o título de paraíso terrestre. O Novo Mundo era, antes de tudo, o verdadeiro Éden na terra; muito diferente da realidade existente na Europa, a fertilidade do solo americano proporcionava os mais diversos frutos e recursos, prontos para serem consumidos, sem a necessidade do labor humano. O conceito edênico foi bem aceito entre os letrados europeus, uma vez que, na Europa, a Cristandade detinha grande parte do poder sobre a população e buscava de alguma maneira reaver Constantinopla e, consequentemente, restaurar o Império Cristão no Oriente. Assim, 'descobrir' um novo continente naquele momento auxiliaria os países europeus a se reerguerem política e economicamente, bem como reconquistarem a simpatia dos fiéis. O primeiro 
contato com os habitantes do Novo Mundo foi descrito por Colombo de maneira a ressaltar a nudez dos nativos e, posteriormente, devido à falta de comunicação verbal. Elogiou-lhes a generosidade, posto que oferecessem seus 'pertences', muitas vezes tratando-se de artefatos feitos de ouro e prata - muito apreciados pelos europeus - e, recebiam em troca objetos de menor ou sem valor. A inocência edênica presente nos primeiros relatos acerca dos nativos do Novo Mundo e, posteriormente, a descrição mais aprofundada de seus hábitos, revelou o paradoxo presente no discurso europeu. Por um lado, um discurso marcado pela negatividade que vai acentuar a nudez, a antropofagia, a comunhão de propriedade como características inferiores e alusivas ao homem selvagem, por outro lado, essas mesmas descrições vão acentuar de maneira positiva o estado natural desses indivíduos, revelando-se por meio do mito do bom selvagem. A Carta de Colombo assemelha-se em certos aspectos, à Carta de Caminha, já que ambas, por meio da retomada dos motivos edênicos, buscavam atrair os olhares da Coroa Portuguesa para a terra conquistada. Apesar disso, podese concluir que, diferentemente da Carta de Colombo, a Carta de Caminha não tenha contribuído com a criação do imaginário europeu acerca da América naquele período, uma vez que, a carta conservou-se inédita por mais de dois séculos, sendo publicada em 1817, cinco anos antes da independência do Brasil.

Datada de maio de 1500, a publicação tardia da Carta de Caminha ocultou o projeto colonial do qual ela fazia parte, de modo que, quando publicada ela foi reinterpretada e usada por escritores e intelectuais brasileiros "como instrumento de articulação de ideias nacionalistas e anticolonialistas" (BRAGA-PINTO, 2003, p. 25), de modo a destacar os ideais liberalistas que advinham do processo de independência. O projeto colonial português baseavase em uma tradição europeia antiga e muito difundida, que afirmava a existência de reinados convertidos ao cristianismo na África e na Índia, por São Tomé, no século III d.C. A Coroa Portuguesa inicialmente não buscava a expansão do cristianismo e, ao mesmo tempo, a restauração de Jerusalém como o projeto espanhol do qual Colombo fazia parte, todavia, procurava por outros reinos que já fossem cristãos, de modo a restaurar a religião. Conforme apontou a seguinte passagem:

A importância alcançada por esse mito em Portugal pode ser indicativo da formação de um novo discurso, no qual a Terra Prometida e o centro do mundo não estavam em algum lugar fora da Europa, mas na Cristandade europeia ou, mais especificamente, em Portugal. Em vez de simplesmente expandir o alcance geográfico da Cristandade, os portugueses procurariam, nos quatro cantos do mundo, outros reinos que já fossem cristãos. (BRAGA-PINTO, 2003, p. 38-39)
A Carta de Caminha não faz alusões ao mito subjacente no discurso da expansão portuguesa, nem sugere que a expedição buscasse reinos cristãos, contudo, no texto A Relação do Piloto Anônimo, a viagem de Cabral é descrita como repetição da viagem de Vasco da Gama e, é possível perceber como o viajante estava determinado a descobrir e estabelecer comunicação com reinos cristãos ultramar. Assim, a viagem de Vasco da Gama não pode ser dissociada desse discurso que invoca a restauração da Cristandade, e, além disso, a comunicação linguística e geográfica entre esses reinos estabeleceria laços comerciais dos quais Portugal se beneficiaria. Mesmo que, em um primeiro momento, o 'descobrimento' do Brasil tenha sido um fato possivelmente marginal para os portugueses, verifica-se que naquela época nenhuma descoberta estava fora do projeto expansionista daquele país. Com isso, a Carta de Caminha objetivava retratar a nova terra e o contato com seus habitantes, destacando o que parecia ser mais admirável: a inocência dos povos do lugar. Segundo Braga-Pinto (2003) a falta de roupas dos nativos e a falta de preocupação em cobrir seus órgãos sexuais são apreendidas como ideal moral a ser alcançado pelos europeus, pois, na visão de Caminha, a nudez dos índios remetia aos excessos dos povos da Europa e, também, a falta de inocência original que permeava esses povos. Enquanto ideal a ser alcançado, a inocência original dos nativos era, aos olhos do escrivão, uma marca de superioridade almejada pelos europeus, aqui se pode fazer uma aproximação ao mito do bom selvagem - mais tarde ratificado nas obras de Montaigne, que afirmava que os habitantes do Novo Mundo eram em muitos aspectos superiores aos europeus.

A publicação tardia da Carta de Caminha ocultou o projeto colonial do qual ela fazia parte, mas sua leitura permite compreender como se deu o processo de evangelização desses povos. Apesar de a Carta de Caminha ter se conservado inédita por dois séculos, a notícia de terras mais ao sul do que daquelas encontradas por Cristóvão Colombo, chegaram ao conhecimento da Europa culta, no ano de 1507, pela boca de um anônimo e em língua italiana (FRANÇA, 2012, p. 87). Apesar disso, não se deve pensar que a notícia logo se espalhou pelo continente europeu. Segundo França (2012) que analisou o processo de construção do Brasil e dos brasileiros nos relatos de viagem dos séculos XVI, XVII e XVIII, as notícias sobre o Brasil se deram de maneira lenta e gradativa, restringindo-se, aos que dominavam a escrita e a imprensa. Além disso, França (2012) asseverou que, até o ano de 1576, a contribuição dos portugueses em termos de publicações sobre as terras brasileiras foram insignificantes e, alcançaram apenas uma pequena parcela dos europeus, de modo, que 
'quase nada do que os portugueses deixaram registrados colaborou efetivamente para a construção do Brasil no pensamento europeu'. Ainda que a literatura produzida pelos portugueses não tenha contribuído com a criação do imaginário europeu naquele período, de certo modo, ela refletiu o pensamento europeu sobre as terras conquistadas.

Dessa forma, cartas escritas pelos jesuítas além de terem sido usadas como instrumentos de informação que procurava reforçar a rede espiritual dos missionários e retratar a experiência religiosa - oferecem um mapa retórico que ilustrou o processo de conversão dos gentios, efetivada a partir de 1530; conforme apontou Pécora (2001, p. 28), a presença ostensiva da carta no corpo da Companhia "evidenciou que sua função estava pensada ao menos segundo três aspectos decisivos: o da informação; o da reunião de todos em um; e, enfim, o da experiência mística ou devocional". Ademais, nas cartas trocadas entre os missionários é possível apreender a visão ambivalente que permeava a descrição dos gentios durante o processo de conversão religiosa. Caminha fundamentou a conversão e, posteriormente, a intervenção jesuítica, com base na existência de uma identidade religiosa comum entre índios e europeus, ou seja, de alguma forma os nativos já seriam cristãos e, que apesar de suas más práticas e pecados (a nudez, poligamia, antropofagia), eles possuiriam uma disposição original para o bem, nesse caso sinônimo de Deus. Portanto, acredita-se que as práticas 'selvagens' dos nativos não significava que elas eram advindas de uma má natureza, o método de conversão adotado pelos missionários era marcado pela pregação dos argumentos de fé - a chamada via amorosa, caracterizada pelos seguintes métodos:

A visita e pregação desarmada dos padres nas aldeias; o exemplo de vida dos missionários e a existência de uma justiça eclesiástica capaz de coibir os abusos dos sacerdotes de outras ordens; a pregação sistemática dos índios adultos; o ensino de leitura e escrita do português, além da doutrina religiosa aos pequenos; o esforça de aprendizado das línguas indígenas, de tradução de textos doutrinais e orações cristãs; a realização de festas, procissões e ofícios, com seus cantos, rezas, disciplinas e ministério dos sacramentos; a separação dos índios já batizados dos demais, para que não recaiam em antigos costumes gentios; o castigo exemplar dos conversos que pratiquem atos contranatura ou injuriosos à religião cristã entre outros. (PÉCORA, 2001, p. 47)

Segundo Nóbrega (1931 apud PÉCORA, 2001, p. 46):

Ao converter todo este Gentio é mui fácil cousa, mas o sustental-o em bons costumes não póde ser sinão com muitos obreiros, porque em cousa nenhuma crêm e estão papel branco para nelles escrever vontade, si com exemplo e continua conversão os sustentarem.

Pode-se notar nas palavras de Nóbrega (1931) a presença da metáfora do 'papel em branco' que serve para ressaltar a inexistência de resistência à conversão jesuítica por parte dos nativos, de modo que a conservação dos bons hábitos conviria para sustentar a conversão. Contudo, as hostilidades não demoraram a aparecer, no governo de Duarte da Costa (1553-57), as disposições favoráveis dos índios - descritos como obedientes e fáceis de senhorar - são questionadas a partir da designada 'guerra dos índios', quando cinquenta indígenas de uma aldeia revoltaram-se atacando os engenhos. Esse episódio fez com que o discurso de Nóbrega distanciasse da pregação dos argumentos de fé e principie a postular que o êxito da missão missionária no Novo Mundo deveria constituir-se de práticas severas de punição aos indígenas. A via da experiência como ficou conhecida, pregava a conversão dos indígenas pelo medo; nas cartas trocadas entre os missionários, eles começavam a exigir a sujeição política dos indígenas; concomitantemente, o governo de Mem de Sá aplicava punições às práticas condenadas pela igreja e oferecia proteção aos jesuítas das ameaças de um possível ataque dos nativos. Apesar disso, as descrições das paisagens e clima conservavam o caráter positivo, acentuando a fertilidade da terra, variedade da fauna, exuberância da flora, clima salubre e o sinal da onipotência do Criador - representações feitas por Caminha e Nóbrega, que ficaram muito próximas das produzidas pelos demais países da Europa. A seguir um trecho de uma carta de Nóbrega, retirado do livro Visão do Paraíso de Holanda (1996), no qual ele descreveu a cidade sede do governo geral, em 1549:

É muito sã e de bons ares [...]. É terra muito fresca, de inverno temperado, e o calor do verão não se sente muito. Tem muitas frutas e de diversas maneiras, e muito boas, e que têm pouca inveja às de Portugal. Os montes parecem formosos jardins e hortas, e certamente eu nunca vi tapeçaria de Flandres tão formosa, nos quais andam animais de muitas diversas maneiras, dos quais Plínio nem escreveu nem soube. Tem muitas ervas de diverso olor e muito diferentes das de Espanha, e certamente bem resplandece a grandeza, formosura e saber do Criador em tantas, tão diversas e formosas criaturas. (NÓBREGA, 1931 apud HOLANDA, 1996, p. 244)

Nos séculos seguintes, as imagens produzidas sobre o Novo Mundo pela literatura de viagem, bem como em romances ambientados em países imaginários que preservavam a descrição das paisagens tropicais do novo continente, pareciam corresponder aos aspectos vistosos 
e raros, ao poder de sedução que as belezas das paisagens exerciam bem como o préstimo que delas podiam tirar. As descrições do homem americano, no entanto, obedeciam aos interesses dos colonizadores que se encarregavam de criar aspectos positivos e negativos de acordo com o maior ou menor grau de resistência oposto a eles. Em meados do século XVIII, a partir das ideias difundidas por Buffon com o livro Historie naturalle (1749) e em Recherches philosophiques (1783), de De Pauw acerca da 'inferioridade' do meio americano e da 'fraqueza' das espécies animais e humanas, essa visão 'quase' paradisíaca da América começou a ficar comprometida pela negatividade que marcava as teorias desses naturalistas. Mesmo sem nunca ter pisado em terras americanas, de acordo com Gerbi (1996) Buffon dedicou-se a estudar as espécies da América. A base de seus estudos eram os vários escritos descritivos da natureza, flora e fauna americana produzida pelos cronistas e demais naturalistas que passaram pelo novo continente e trataram de coletar e descrever espécimes do Novo Mundo. A partir de observações sobre os animais da América, Buffon constatou que eles eram diferentes aos do Velho Mundo. Inicialmente, ele apresentou uma comparação entre o leão americano (puma) e o leão europeu e, apontou uma série de diferenças que inferiorizavam o animal americano, entre elas, a falta de juba, seu tamanho inferior, sua fraqueza e covardia em comparação ao animal do Velho Mundo (GERBI, 1996). Segundo Gerbi (1996, p. 16), "a fulminante intuição do confronto entre o puma e o leão subitamente se estende a toda a série dos grandes mamíferos". Como se sabe, Buffon ultrapassou os limites da zoologia e estendeu suas observações e análises aos homens americanos, dessa vez seu modelo foi o homem europeu. E, ao relacionar o nativo americano e a natureza hostil, ele chegou ao mesmo ponto: a inferioridade dos animais é a mesma que a dos homens (GERBI, 1996).

[...] ainda que o selvagem do Novo Mundo possua aproximadamente a mesma estatura do homem de nosso mundo, isso não é suficiente para que ele constitua uma exceção ao fato geral do apequenamento da natureza viva em todo este continente. O selvagem é débil e pequeno nos órgãos de reprodução; não tem pelos nem barba, nem qualquer ardor por sua fêmea: embora mais ligeiro que o europeu, pois possui o hábito de correr, é muito menos forte de corpo; é igualmente bem menos sensível e, no entanto, mais crédulo e covarde; não demonstra qualquer vivacidade, qualquer atividade d'alma; quanto à do corpo, é menos um exercício, um movimento voluntário, que uma necessidade de ação imposta pela necessidade: prive-o da fome e da sede e terá destruído simultaneamente o princípio ativo de todos os seus movimentos; ele permanecerá num estúpido repouso sobre suas pernas ou deitado durantes dias inteiros. (BUFFON, 1749 apud GERBI, 1996, p. 21)
Segundo Gerbi (1996) pode-se constatar de acordo com Buffon que ele considerou o homem americano débil e indolente. A culpa de a natureza ser imperiosa era daquele homem que não fazia nada para moldá-la ou extrair dela os meios para sua sobrevivência. Buffon estabeleceu, ainda, uma relação de semelhança entre a frieza do nativo à dos repteis e insetos que "pululam frequentemente com dimensões gigantescas" (GERBI, 1996, p. 21). Se, por um lado, o continente americano é hostil aos grandes animais, por outro, ele é favorável à proliferação de artrópodes devido à umidade e insalubridade do solo e clima.

Na visão de Gerbi (1996) um pouco mais radical que Buffon era De Pauw, que considerava o homem americano um animal, um degenerado, um monstro, não obstante, também concordava com a tese de Buffon, de que a natureza americana possuía influência sobre o nativo e funcionava como um obstáculo que impedia o seu desenvolvimento máximo. Do mesmo modo, o ar insalubre seria responsável pela propagação de insetos e répteis e pela degeneração dos animais e homem americano. De maneira geral, o que foi retomado ao longo dos séculos por vários autores, alude ao clima, que de "ameno e salubre no século XVI termina o século XVIII com a reputação de excessivamente quente e, o que é pior, insalubre" (FRANÇA, 2012, p. 200); a exuberância da flora, não sofre variações nos diversos relatos sobre o Brasil; a diversidade da fauna, exaltada principalmente, em relação à variedade de pássaros e a fertilidade do solo, que era retratado como se não carecesse do labor humano para manter-se vigorosa, em meados do século XVIII, sofrem com a tese do naturalista Conde de Buffon sobre a 'debilidade' das espécies animais da América. Segundo Ventura $(1987$, p. 29) a partir da independência política das colônias da América, que aconteceu aproximadamente ao final do século XVIII e início do século XIX, "perderam-se, na Europa, os temas específicos suscitados por Buffon, que deixou de exercer, com o 'fim da história natural', influência como cientista". Diante disso, o fim do domínio colonial implicou uma ampla negociação das relações entre América espanhola e Europa relações políticas e econômicas e, com igual relevância, relações de representação e imaginação; esse período correspondeu ao que Pratt (1999) chamou de reinvenção da América.

Para as elites da Europa setentrional, a reinvenção é ligada a prospectos de grandes possibilidades expansionistas para o capital, tecnologia, mercadorias e sistemas de conhecimento europeus. As elites recémindependentes da América espanhola, por outro lado, se deparavam com a necessidade de autorreinvenção no que se referia às massas europeias e não europeias que procurariam governar. (PRATT, 1999, p. 197) 
Em decorrência do processo de independência, as colônias espanholas estavam livres para manter relações diretas, econômicas e políticas, com os demais países da Europa. Até aquele momento, isso não era possível, pois vigorava o protecionismo hispânico que mantinha os portos da América Espanhola fechados, tanto para mercadorias quanto para quase todas as pessoas estrangeiras.

No Brasil, o mesmo acontecia desde os quinhentos, os estrangeiros mantinham relação com as colônias portuguesas pelos portos das cidades litorâneas, que recebiam produtos e escravos de fora. Além disso, a Coroa Portuguesa detinha total domínio de exploração sobre as colônias e funcionava como agente negociador da matéria prima, fruto da exploração, para os demais países da Europa. Com o fim desse regime, os capitalistas europeus, a fim de acelerar a produção, intensificar a demanda de mercado e expandir o capital, buscavam um comércio mais direto com o estrangeiro. Em contrapartida, os colonos independentes proprietários de terras buscavam expandir o mercado consumidor e, para isso, eles tinham a necessidade de atrair os olhares europeus. Pratt (1999) destacou os escritos de Friedrich Wilhelm Heinrich Alexander von Humboldt ${ }^{1}$ como fator importante na reinvenção discursiva e ideológica da América do Sul durante as primeiras décadas do século XIX. Segundo Pratt (1999) Humboldt reinventou a América do Sul, principalmente, enquanto natureza, fator que restaurou a imagem paradisíaca do continente.

Baseado nisso, num primeiro momento, a escrita de Humboldt sobre a América do Sul se definiu segundo o projeto científico, isto é, a descrição física da paisagem que definia e representava o território americano. No entanto, foi com a publicação de seus escritos não técnicos, que mesclavam os detalhes científicos com o discurso romântico do sublime, entre eles; Imagens da natureza (1808) e Imagens da cordilheira e monumentos dos povos indígenas da América (1810) e Narração pessoal de suas viagens obra inacabada que teve o terceiro volume publicado em 1825 - que Humboldt conseguiu atingir o público leitor europeu e reinventar o imaginário americano. Em suas descrições sobre a América do Sul, Humboldt retomou a ideia de natureza exótica, como fizeram os primeiros conquistadores e, colocou o continente como um lugar privilegiado, no qual as 'forças ocultas' impulsionavam a paisagem. Distante das ideias de Buffon e De Pauw que inferiorizam os aspectos da natureza americana, Humboldt estava totalmente ancorado no discurso romântico europeu, à medida

\footnotetext{
1 Geógrafo, naturalista e explorador alemão.
}

que se apropriou da estética do sublime e mesclou-a ao científico (PRATT, 1999). De acordo com Pratt (1999) apesar de Humboldt não fazer longas observações sobre o homem americano, após as primeiras providências em relação aos nativos no século XVI, como a atividade missionária e a sua possível conversão e, posteriormente, a guerra e o extermínio dos mesmos, o conceito do 'bom selvagem' surgido no período clássico é revivido no Renascimento, com a titulação de Nobre Selvagem. Concomitantemente ao período que se designou a reinvenção da América, o motivo classicista do bom selvagem é retomado principalmente após as contribuições de Jean-Jacques Rousseau, como motivação para políticas e práticas contra o genocídio e exploração desses povos. White (1994, p.212) afirmou:

O uso do termo pacificação para designar políticas e práticas de genocídio é importante, porque significa o advento de um quarto momento na história das relações das raças no período entre a Renascença e o final do século XVIII. Esse novo momento é assinalado pela aceitação geral da ideia do Nobre Selvagem. [...] a ideia do Nobre Selvagem estava presente tanto no pensamento clássico quanto no cristão, e foi revivida durante o Renascimento, embora nunca com o entusiasmo que caracterizou seu uso durante a segunda metade do século XVIII - e principalmente depois de Rousseau.

No entanto, White (1994) apontou que o motivo do Nobre Selvagem e sua popularidade iam além da possibilidade de dignificar o selvagem do Novo Mundo, antes servia para reafirmar o conceito de nobreza que predominava na Europa. Apesar disso, o conceito foi aproveitado de forma que atribuiu um tratamento mais humano aos nativos, ocorrência que ele asseverava tratar-se de uma ideia fetichista, pois o seu verdadeiro referente estava longe de ser os 'selvagens'. De tal modo, o caráter fetichista do mito do 'bom selvagem' que estava relacionado à raça e às qualidades superiores dos nativos do Novo Mundo, a partir da Revolução Francesa é moldado conforme as necessidades ideológicas da população europeia, de modo a caracterizar o fetichismo de classe. À medida que o mito compartilhava de interesses tanto da população europeia como de filósofos que defendiam a classe dos nativos, o conceito de Nobre Selvagem obteve ampla aceitação.

Desse modo, essas representações constituem uma fonte de informação fundamental para que se possa compreender a visão dos europeus sobre as terras descobertas, bem como ilustrar os conceitos eurocêntricos acerca do 'outro'. 


\section{O olhar da estrangeira}

Ao considerar-se que Marie van Langendonck tenha absorvido o conceito de paraíso terrestre retomado por seus contemporâneos, acompanha-se a forma como essa visão vai sendo desconstruída até o momento em que resolve abandonar a colônia, de maneira que, a admiração pela natureza intocada brasileira não lhe foi suficiente para sustentar sua nova identidade, a de imigrante trabalhadora. Diante de uma sociedade que há pouco havia declarado sua independência, os temas de seus julgamentos estavam intrinsecamente relacionados aos elementos que compõem a sociedade brasileira pós-independência - o colono, o indígena, o escravo, a mulher e a política. À medida que a narradora apresentava uma vida pioneira pouco atraente, descortinava uma avaliação negativa do processo de colonização e deixava transparecer o sentimento de ruptura e solidão que compunha a própria identidade do imigrante.

Diante disso, Mme. van Langendonck corroborava em sua narrativa o paradoxo do olhar da estrangeira, antes mesmo de decidir-se por emigrar para o Brasil, pois idealizou o espaço a partir de um modo de vê-lo "previamente determinado por uma série de crônicas, relatos, notícias, romances, por uma sucessão de miradas estrangeiras ou não, que demarcam os contornos, tonalidades, sombreados do território brasileiro" (SUSSEKIND, 1990, p. 32). Encantada pela visão paradisíaca herdada de um imaginário europeu, a expectativa pelo novo e desconhecido não deixou de permear sua trajetória. Do mesmo modo que a estética do sublime $^{2}$ permeou o olhar do estrangeiro sobre os países da América do Sul no período Renascentista, o discurso de Mme. van Langendonck recuperaria a natureza americana como fonte de inspiração, permitindo a ela afastar-se de seu país de origem e fixar seu olhar na observação dessa paisagem.

No entanto, a ambiguidade presente ao longo dos séculos no discurso europeu parece acompanhar as avaliações que Mme. van Langendonck fazia dos costumes, da gente brasileira e até mesmo da paisagem que a atraiu, de modo que seus julgamentos sofreram oscilações durante todo o seu relato. O relato de Marie oferece uma ideia de como era organizado o transporte de emigrantes alemães, a maneira como ela enxergava os mesmos bem como, a posição que ela ocupava no navio e na sociedade. A imigração no Sul do Brasil iniciou-se em 1824 e, e foi realizada pelo governo brasileiro; no

\footnotetext{
Faz-se necessário esclarecer que a noção de sublime aqui compreendida está relacionada à categoria estética difundida a partir de meados do século XVIII, na qual o sublime é atingido à medida que a obra consegue provocar sensações duradouras, na qual a sensibilidade se volta para aspectos extraordinários e grandiosos da natureza.
}

ano de 1855, a Sociedade Montravel, Silveira \& Cia, fundada no mesmo ano, fora reconhecida como empreendimento particular autorizado pelo governo imperial. A Sociedade assumia o compromisso de introduzir 1440 colonos na província, mediante um adiantamento de quinze mil réis por colono, além de um empréstimo de cinquenta e sete contos de réis. Assim, os colonos recém-chegados, poderiam dar início ao cultivo da terra na colônia no Rio Grande do Sul. No percurso da viagem, Langendonck (2002, p. 25) apresentou o grupo que compunha a coberta do navio, "indivíduos de todas as idades e de todos os sexos" e, deixa claro que todos haviam pagado por suas passagens, portanto, todos eram "colonos livres". No entanto, ela evidenciou uma diferença e uma semelhança entre eles. A divergência é que "alguns carregavam consigo uma pequena fortuna, seja em espécie, seja em mercadorias. Outros haviam sido embarcados à custa de suas comunidades" (LANGENDONCK, 2002, p. 25), fato que lhes conferiu um regime alimentar distinto, pois os que possuíam algum dinheiro estavam abastecidos com suprimentos, os outros, que nada tinham, eram obrigados a comer 'rações de bordo' para não morrerem de fome. A similitude encontrou-se baseada nas circunstâncias de higiene, "todos tinham em comum uma sujeira sem nome, além de costumes que ao mais indulgente teriam parecido de uma licenciosidade bastante evidente" (LANGENDONCK, 2002, p. 25). Pode-se inferir que Marie tentou ser tolerante frente aos costumes dos viajantes alemães, mas por fim ela asseverou que nem mesmo a pessoa mais complacente poderia compreender a falta de asseio e negligência a que estavam habituados. As observações foram criando um espaço superior para si, destacando uma hierarquia progressiva dos aspectos físicos aos mais abstratos. A disposição por ela ocupada no navio proporcionava uma ampla visão dessas pessoas, mas a distanciava da convivência, circunstância que ela estimava, e reiterava o desconforto na visão:

A cabine do capitão, excessivamente pequena, estava situada no mesmo nível da cobertura. Entre as duas havia nos reservado um espaço, contendo duas camas e o lugar necessário a nossas bagagens, de maneira que estávamos perfeitamente à vontade. Nossa cabine improvisada recebia luz por dois globos de vidro, incrustados na ponte. Sós, quando o desejávamos, fazendo nossas refeições em família, inicialmente não achamos a travessia sem conforto nem sem encanto. Ai de nós! Chegamos às regiões quentes, sufocávamos na cabine, forçoso nos foi ir buscar um pouco de ar na ponte. Toda a população do Amanda lá estava permanentemente, não sabíamos onde nos enfiar. $O s$ alemães continuamente faziam uns aos outros o favor mútuo de catarem os vermes que os cobriam. O nojo deste espetáculo era atroz, e como o capitão deixava 
a popa à disposição de todos, era, pois, impossível evitá-lo ${ }^{3}$. (LANGENDONCK, 2002, p. 26)

Na passagem acima, é possível notar que o capitão, a família de Mme. van Langendonck e os alemães estavam dispostos no mesmo nível, o da cobertura do navio, lugar destinado aos imigrantes. Contudo, uma cabine ainda que 'improvisada', separada dos demais viajantes fora concedida à sua família, de modo que, Mme. van Langendonck não se encontrava acomodada nem em meio aos alemães, nem junto ao capitão, mas entre os dois posição que lhe conferia alguns privilégios, certo grau de conforto, privacidade e a manutenção do convívio familiar.

O tratamento e disposição diferenciados de sua família remetem à sua posição na sociedade; ainda que os Langendonck tenham sido uma família belga aristocrata de poucas posses, Mme. van Langendonck sempre frequentou a corte, os meios literários e culturais, de maneira que possuía uma relativa influência entre os membros da nobreza e esses privilégios transpareceram na passagem acima - cabine 'improvisada' para sua família. Nesse caso, a hierarquia de classes além de separá-la do convívio com os demais viajantes igualmente apontou para o fato de que os imigrantes e Marie dividiam propósitos divergentes. No entanto, os fatos apresentados por Marie são continuamente imbuídos pelos seus juízos de valor, tendo ela considerado desumano nos alemães aquilo que não é adotado como prática costumeira de seu país, assim como Montaigne (1961, p.261) apontou no capítulo Dos Canibais, "cada qual considera bárbaro o que não se pratica em sua terra". Com relação aos colonos holandeses, ela admitiu que, aqueles que ela conheceu não tiveram muita sorte e atribuiu o fracasso desses à falta de coragem moral e física. Por meio de três exemplos distintos, ela comprovava que muitos holandeses foram seduzidos pelos agentes da colonização na Holanda, - que espalhavam folhetos proferindo que "no Brasil cada riacho possuía um leito de diamantes e de pedras semipreciosas, que aí se encontrava o ouro por toda parte [...]. Que a terra produzia sem cultura" (LANGENDONCK, 2002, p. 57-58), entretanto, ao chegarem ao solo brasileiro, os holandeses se deparavam com a precariedade da vida na colônia e os obstáculos que teriam de enfrentar. Diante da dimensão da terra que eles teriam que desmatar para, posteriormente, cultivar o solo e o tempo que teriam que esperar para recuperar o dinheiro investido, os holandeses viram-se desenganados e muitos adoeciam ou morriam de desgosto. Na passagem a seguir, Marie conversava com um deles, e fica evidente o desengano do holandês que abandonara um bom emprego em sua pátria acreditando na promessa de enriquecer rapidamente.

\footnotetext{
3 Grifo da autora.
}

- Meu Deus, senhora, que fiz eu deixando a Holanda, onde tinha assegurado meu pão? Jamais, poderei, sozinho, ganhar, aqui, a vida, para minha mulher e dentro em breve, quatro filhos. [...] O infeliz explodiu em soluços: - Não verei, disse ele, nem um outro ano nem mesmo um outro mês, o engano foi grande por demais, não resistirei [...] No dia seguinte, à noite, a febre lhe causou um delírio que durou três dias; no quarto, a mulher de Sneider estava viúva. (LANGENDONCK, 2002, p. 59-60)

Nesse caso, a promessa de riqueza parecia suficiente para configurar o ato migratório, contudo, $\mathrm{o}$ afastamento do mundo civilizado, em um lote em área recém-demarcada, sem estradas, e diante de práticas agrícolas rudimentares serviram para desencorajar o viajante. Em contrapartida, diante das mesmas circunstâncias a família de Mme. van Langendonck assumiu sua nova identidade, de imigrante trabalhador e, não se deixou abater por essas dificuldades, pois acreditavam que a persistência e o trabalho lhes proporcionariam a estabilidade financeira que procuravam. A família de Marie era a terceira que chegava para se instalar nas terras concedidas pela Sociedade Montravel, e assim que surgiu uma oportunidade, ela tratou de tomar conhecimento sobre as técnicas agrícolas usadas para cultivar o solo. O procedimento consistia, inicialmente, na derrubada da mata nativa, seguida pela queima da vegetação. A família de Marie teve inevitavelmente que se adaptar a esse processo, uma vez que essa situação envolvia a regressão aos padrões culturais inferiores pois na Europa o método utilizado para o preparo do solo havia há muito superado a técnica indígena. A coivara era utilizada principalmente em agricultura de subsistência, por pequenos proprietários de terra ou em áreas de plantio comunal e acarretava o rápido esgotamento do solo. Segundo Langendonck (2002, p. 53):

A falta quase total de vias de comunicação obrigava a destruição, pelo fogo, da madeira cortada. Os troncos que não se conseguia queimar ficavam apodrecendo ao ar livre, o que não impedia que plantássemos em volta. No entanto, que imenso rendimento não dariam essas belas madeiras, enviadas à Europa, para a marcenaria e a construção.

Pode-se notar que além do solo, toda a madeira da derrubada das árvores também era queimada, circunstância que ela recriminava. Contudo, suas explanações não reconheceram os efeitos maléficos da derrubada de árvores, principalmente das matas ciliares; ela avaliava esse processo conforme as perdas financeiras, uma vez que ela considerava um desperdício não utilizar essa madeira na confecção de móveis, na construção civil, ou como produto de exportação. Suas observações almejavam um fim prático e lucrativo conduzido por noções de 
reaproveitamento de materiais, uma visão marcadamente europeia que reconhecia as limitações da natureza, diferentemente dos povos americanos acostumados com a natureza exuberante. As dificuldades relacionadas à colonização se estendiam à falta de atendimento médico na colônia. São inúmeros os casos relatados por Marie de pessoas que morreram antes de conseguirem se consultar, seja pelo planejamento precário e falta de recursos que afetaram as colônias oficiais (administradas pelo Estado) e particulares, seja pela distância que os doentes deveriam percorrer para serem atendidos; esses fatores acarretaram um alto índice de mortalidade principalmente entre crianças e mulheres. De acordo com Marie:

A sociedade pagava um médico, que, todas as quartasfeiras, durante duas horas, os colonos podiam ir consultar no rancho da administração. Aqueles que a doença retinha em suas casas se curavam sozinhos ou morriam sem que ninguém se inquietasse com isso. (LANGENDONCK, 2002, p. 62)

Em uma ocasião, a precariedade do atendimento médico na colônia a dispôs diante de uma circunstância que até então não havia presenciado, Mme. van Langendonck deparou-se com os costumes e crenças indígenas e se surpreendeu com o que viu. Em um de seus passeios à casa de uma vizinha, enquanto tomava chá mate - bebida a qual Marie deixou claro ter se habituado - presenciou a aproximação de um holandês caminhando com dificuldade e, que trazia em seus braços um menino de três anos e outro mais velho que ele procurava manter próximo. $\mathrm{O}$ pobre homem mostrou as hérnias que afligiam seus filhos e acrescentou que precisava ir ao rancho ver o médico. A vizinha contestou que era inútil procurar por um médico e os convidou a retornar no domingo, pois ela mesma os curaria. No dia marcado, movida, de um lado, pela curiosidade, de outro pela descrença, a estrangeira voltou à casa da vizinha para testemunhar o acontecimento. $\mathrm{O}$ olhar da estrangeira descreveu a cena:

Quando chegaram perto da figueira, a Senhora Maximiliano aplicou a planta do pé descalço de uma das duas crianças contra a árvore, traçou com a ponta de uma faca o contorno do pé na casaca da árvore; recolocou o mesmo pé (aquele do lado em que se encontrava a hérnia) transversalmente sobre esta primeira marca e traçou um segundo contorno que cruzava o primeiro. Fez a mesma operação com o pé da outra criança. Então, destacou a casaca, que se achava entre o traçado dos quatro contornos e fechou em um pequeno saco de tecido trazido com este objetivo [...]. Confesso que minha confiança no sucesso da operação não era muito profunda. (LANGENDONCK, 2002, p. 64)
A descrição minuciosa, a elucidação dos detalhes do ritual vistos pela primeira vez causou-lhe estranhamento e despontou na incredulidade da estrangeira acerca dos meios utilizados pela vizinha com o propósito de curar a hérnia dos dois garotos. A mesma descrença também se apropriava do pai dos meninos, no entanto, o desespero dele era tamanho que mesmo não reconhecendo a prática medicinal da Senhora Maximiliano, compactuou com o intento. Após o ritual, o pai "voltou da floresta inteiramente perplexo e evidentemente foi embora menos convencido do sucesso do que na sua primeira visita" (LANGENDONCK, 2002, p. 65).

Certamente, o primeiro contato com uma cultura tão diferente cujos benefícios lhe eram desconhecidos originavam a dúvida que assombrava os dois estrangeiros, Marie e o pai das crianças e, pode ser justificado à medida que o pensamento europeu do século XIX, não reconhecia métodos não comprovados cientificamente. À medida que a narradora traçou um retrato oitocentista da colônia segundo seu ponto de vista, a imagem que ela possuía do navio, dos costumes alemães e holandeses, a avaliação do planejamento precário das colônias, a incredulidade frente às curas da Senhora Maximiliano e a destruição das matas ciliares, reforçaram as questões sociais daquele momento histórico.

Ademais, o relato de Marie asseverava a figura feminina como fonte histórica, uma vez que, foi por meio do olhar crítico de Marie, elitista e conservador, das suas expressões e apreciações, que não buscavam exclusivamente despertar verossimilhança, mas apresentava a possibilidade de fazer história segundo um ponto de vista pessoal, que afirmavam sua autoridade como testemunha histórica.

\section{Referências}

BRAGA-PINTO, C. As promessas da história: discursos proféticos e assimilação no Brasil colonial (1500-1700). São Paulo: Edusp, 2003.

FRANÇA, J. M. C. A construção do Brasil na literatura de viagem dos séculos XVI, XVII e XVIII: antologia de textos (1591-1808). São Paulo: Unesp, 2012.

GERBI, A. O novo mundo: história de uma polêmica 17501900. São Paulo: Companhia das Letras, 1996.

HOLANDA, S. B. Visão do paraíso: os motivos edênicos no descobrimento e colonização do Brasil. São Paulo: Brasiliense, 1996.

LANGENDONCK, Madame Van. Uma colônia no brasil. Tradução de Paula Berinson. Florianópolis: Editora Mulheres: Edunisc, 2002.

MONTAIGNE, M. Dos Canibais. In: MONTAIGNE, M. Ensaios: livro I. Porto Alegre: Globo, 1961.

NUNES, B. A visão romântica. In: GUINSBURG, J. (Org.). $O$ romantismo. São Paulo: Perspectiva, 2011. p. 51-74. 
PÉCORA, A. A arte das cartas jesuíticas do Brasil. In: PÉCORA, A. Máquina de gêneros. São Paulo: Edusp, 2001. p. 17-68.

PRATT, M. L. Os olhos do império: relatos de viagem e transculturação. Bauru: Edusc, 1999.

ROSENFELD, A.; GUINSBURG, J. Romantismo e classicismo. In: GUINSBURG, J. (Org.). O romantismo. São Paulo: Perspectiva, 2011. p. 261-274.

SUSSEKIND, F. O Brasil não é longe daqui: o narrador, a viagem. São Paulo: Companhia das Letras, 1990.

VENTURA, R. Estilo Tropical: a natureza como pátria. Remate de Males, Campinas, v. 7, p. 27-38, 1987. Disponível em:<http://www.iel.unicamp.br/revista/index.php/remate/ article/view/2955/2438>. Acesso em: 16 mar. 2013.

WHITE, H. O tema do nobre selvagem como fetiche. In: WHITE, H. Trópicos do discurso: ensaios sobre a crítica da cultura. São Paulo: Edusp, 1994. p. 203-217.

Recebido: 14 de abril de 2015

Aprovado: 06 de junho de 2015

Contatos:pan chiarelli@hotmail.com

muylaertj@gmail.com

fanitabak@hotmail.com 